Article

\title{
Design and Synthesis of Pro-Apoptotic Compounds Inspired by Diatom Oxylipins
}

Giovanna Romano ${ }^{1, \dagger}, *$, Emiliano Manzo ${ }^{2, \dagger}$, Gian Luigi Russo ${ }^{3, \dagger}$, Giuliana d'Ippolito ${ }^{2, *}$, Adele Cutignano $^{2}$, Maria Russo ${ }^{3}$ and Angelo Fontana ${ }^{2}$

1 Stazione Zoologica Anton Dohrn, Napoli 80121, Italy

2 Institute of Biomolecular Chemistry, National Research Council, Pozzuoli 80078, Italy;

E-Mails: emiliano.manzo@icb.cnr.it (E.M.); adele.cutignano@icb.cnr.it (A.C.); angelo.fontana@icb.cnr.it (A.F.)

3 Institute of Food Sciences, National Research Council, Avellino 83100, Italy;

E-Mails: glrusso@isa.cnr.it (G.L.R.); mrusso@isa.cnr.it (M.R.)

$\dagger$ These authors contributed equally to this work.

* Authors to whom correspondence should be addressed; E-Mails: giovanna.romano@szn.it (G.R.); giuliana.dippolito@icb.cnr.it (G.I.); Tel.: +39-081-5833-430 (G.R.); Fax: +39-081-7641-355 (G.R.); Tel.: +39-081-867-5075 (G.I.); Fax: +39-081-804-1770 (G.I.).

Received: 5 September 2013; in revised form: 29 October 2013 / Accepted: 1 November 2013 / Published: 13 November 2013

Abstract: Oxylipins are a large and diverse family of fatty acid derivatives exhibiting different levels of oxidation of the carbon chain. They are involved in many biological functions in mammals, plants and diatoms. In this last group of organisms, they are suggested to play a role in the reproductive failure of copepod predators, showing clear pro-apoptotic effects on newborn nauplii. In this work, these compounds were tested for the ability to induce mitotic arrest in sea urchin embryos. We show for the first time that oxylipins have an increased efficacy in their corresponding methylated form. Natural oxylipins were also used as an inspiration for the rational design and synthesis of stable chemical analogs with apoptotic activity against tumor cell lines. This approach led to the synthesis of the linear C15-ketol (22) that was shown to induce apoptosis in human leukemia U-937 cells. These results are proof of the concept of the use of eco-physiological considerations as a platform to guide the search for novel drug candidates. 
Keywords: diatoms; oxylipins; chemical synthesis; bioactivity; apoptosis

\section{Abbreviations \\ DIBAL, diisobutylaluminum hydride; THF, tetrahydrofuran.}

\section{Introduction}

Diatoms are a widespread group of marine microalgae that play a pivotal role in primary production and biogeochemical cycles in marine ecosystems. They produce a plethora of bioactive oxylipins, a large and diverse family of secondary metabolites derived from the oxidation of polyunsaturated fatty acids. Most of these compounds arise from oxidation of eicosapentaenoic acid and unsaturated C16 fatty acids catalyzed by specific lipoxygenases (LOXs) with different regio- and stereo-selectivity [1,2]. The extreme variability of the downstream reactions adds great diversity to oxylipin structures that in diatoms include hydroxy-, keto-, epoxyhydroxy-acids and polyunsaturated aldehydes.

Oxylipins are common bioactive secondary metabolites present in mammals as well as in plants, mosses, algae, bacteria and fungi. In mammals, members of the family, such as prostanoids, leukotrienes and thromboxanes, are involved in inflammation and in numerous homeostatic biological functions and also modulate the expression of genes involved in DNA transcription and lipid metabolism $[3,4]$. In plants, $\mathrm{C}_{18}$-derived oxylipins mainly serve as signal molecules regulating developmental processes and are involved in plant stress responses and innate immunity [5-7]. In diatoms, oxylipins have been correlated to the antiproliferative effect of diatoms on predator reproduction [8,9], whereas, with the exception of few studies [10,11], their physiological role as signaling molecules remains largely unexplored. However, while many studies have been reported on the effect of polyunsaturated short-chained aldehydes [12,13], the biological effect of non-volatile oxylipins has been scarcely explored [2,12]. For instance, Fontana and co-workers showed that copepod nauplii hatched from eggs treated with a pool of oxylipins were seriously damaged and had a large proportion of apoptotic tissue, as revealed by terminal deoxynucleotidyl transferase (TdT) dUTP Nick-End Labeling (TUNEL) staining [2]. In the present study, we investigated the activity of different types of natural oxylipins on developmental processes in sea urchin embryos. The structures of these compounds were also used as an inspiration to design and synthesize a series of analogs with pro-apoptotic activity against a human leukemia-derived cell line.

\section{Results and Discussion}

\subsection{Inhibition of Cell Division by Natural Oxylipins}

$15 S$-Hydroxyeicosapentaenoic acid (15(S)-HEPE) (1) is one of the most frequently encountered diatom oxylipins [13]. In agreement with previous studies on copepod nauplii reported in [12], this metabolite inhibited the cleavage in sea urchin Paracentrotus lividus embryos at concentrations higher than $70 \mu \mathrm{M}$ and induced $100 \%$ blockage of cellular division at $94 \mu \mathrm{M}$ (Figure 1a). Nevertheless, the methyl ester of 15(S)-HEPE (2) showed a noticeably higher activity (IC50 $=4.1 \mu \mathrm{M})$ and completely 
arrested division of treated embryos at only $8 \mu \mathrm{M}$. At this concentration morphological alterations similar to those induced by $2 E, 4 E$-decadienal [14] were observed: embryos remained blocked at the zygote stage and after about 90 min some blebbing vesicles became visible (not shown).

Figure 1. Percentage of first cleavage occurrence in sea urchin embryos treated with increasing concentrations of (a) 15S-hydroxyeicosapentaenoic acid (15(S)-HEPE) (\#1), 15(S)-HEPE methyl ester (\#2), eicosapenataenoic acid (EPA) (\#3) and EPA methyl ester (\#4) and of (b) natural oxylipins \#5a-\#8a. Compound numbering is according to the structure reported in Scheme 1. Values (means \pm S.D.; $N=600$ ) are the results of three different experiments.

a)

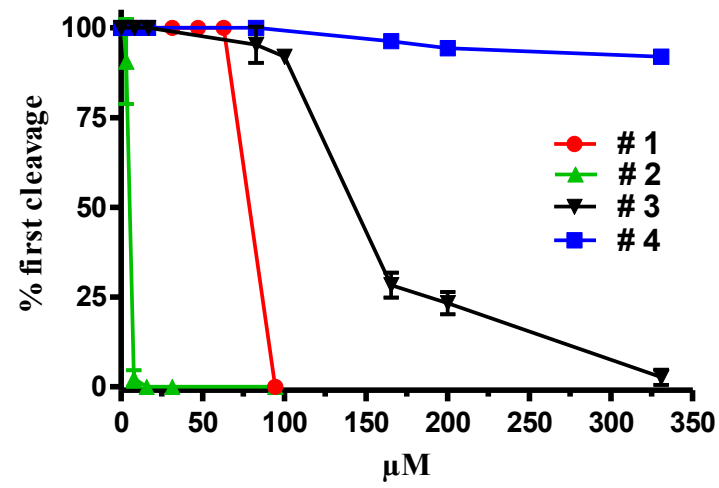

b)

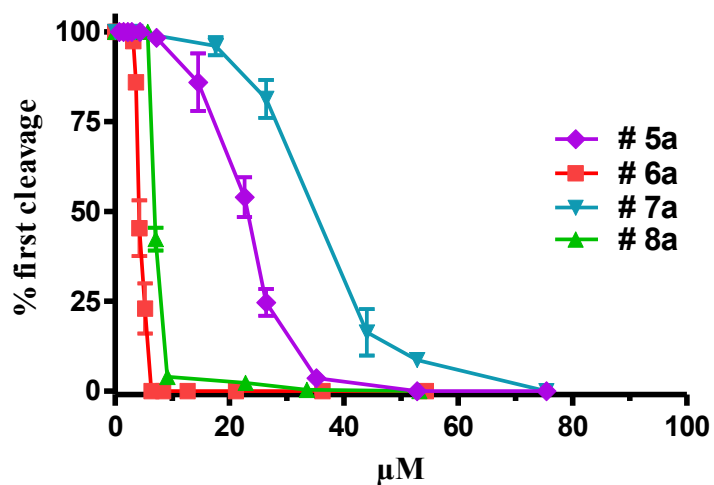

Scheme 1. Structures of typical diatom oxylipins.
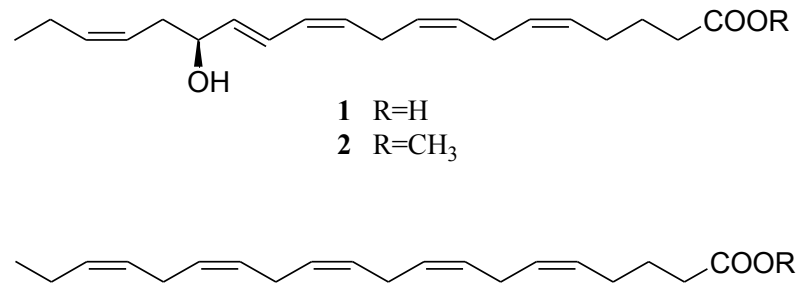

$3 \mathrm{R}=\mathrm{H}$

$4 \mathrm{R}=\mathrm{CH}_{3}$

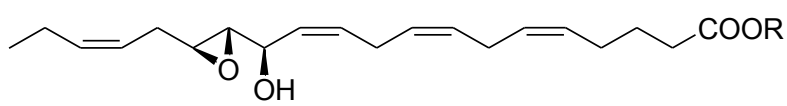

$5 \mathrm{R}=\mathrm{H}$ 5a $\mathrm{R}=\mathrm{CH}_{3}$<smiles>[R]OC(=O)CCCCC(=O)/C=C/C=C\C/C=C\CC=C</smiles>

$\begin{array}{ll}6 \mathrm{R} & =\mathrm{H} \\ \mathbf{6 a} \mathrm{R} & =\mathrm{CH}\end{array}$<smiles>[R]OC(=O)CCCCC/C=C/C(O)CCCCCCC</smiles>

$7 \mathrm{R}=\mathrm{H}$

7a $\mathrm{R}=\mathrm{CH}_{3}$

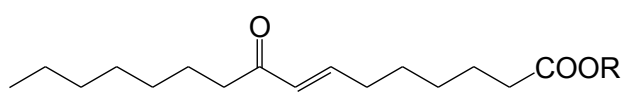

$8 \mathrm{R}=\mathrm{H}$

8a $\mathrm{R}=\mathrm{CH}_{3}$

The antimitotic effect was clearly dependent on the insertion of the oxygenated function, since eicosapenataenoic acid (EPA), as both free carboxylic acid (3) and methyl ester (4), had no significant activity on sea urchin cleavage progression. Differently from the response with 15(S)-HEPE, the methyl ester of EPA (4) was fully inactive up to $330 \mu \mathrm{M}$ (Figure 1a) whereas the free fatty acid (3) started interfering with the development of sea urchin embryos only at concentrations above $165 \mu \mathrm{M}$. At even higher levels $(330 \mu \mathrm{M})$, this compound also blocked cleavage, but the effect was clearly distinguishable from that induced by 2 since embryos treated with high concentrations of EPA (3) 
became progressively diaphanous and after about 90 minutes started to swell and increased in volume with loss of cellular organization.

The unexpectedly potent activity of $\mathbf{2}$ prompted us to investigate other classes of diatom oxylipins. Thus, compounds (5-8) were isolated from different diatom species [1,10] and tested on sea urchin embryos. In analogy with HEPE and EPA, methyl ester derivatives 5a-8a were also prepared from natural products by derivatization with diazomethane.

No activity was found with free carboxylic acids 5-8 at concentrations up to $100 \mu \mathrm{M}$ (not shown) but methylation of the carboxylic function determined a generalized increase of the inhibitory activity of these compounds on development of sea urchin embryos (Figure 1). In agreement with the effect previously described with 15(S)-HEPE (2), compounds 5a and 7a arrested mitotic divisions at 52 and $75 \mu \mathrm{M}$ (IC50 = 22.6 and $33.0 \mu \mathrm{M}$, respectively), whereas compounds 6a and 8a showed a stronger effect and inhibited 100\% egg cleavage at 6 and $9 \mu \mathrm{M}$, respectively (IC50 = 4.2 and $6.9 \mu \mathrm{M}$ ). These results suggested that unsaturated hydroxy- or keto-groups are crucial to enhance the activity of these fatty acid derivatives. Interestingly, these compounds were as potent as decadienal, which is reported to fully block cleavage of sea urchin embryos at $5 \mu \mathrm{M}[14,15]$. Pohnert and colleagues discussed the effect of decadienal and other unsaturated-aldehydes produced by diatoms in relation to non-specific chemical reactivity towards nucleophilic biomolecules [16]. Following other studies on biologically active aldehydes, these authors suggested that the main reaction pathway was the Michael-addition of the unsaturated aldehyde with thiol or amino groups of proteins. These reactions are not specific and, consequently, the adduct formation induces adverse effects on a broad range of cell functions. Similar mechanism could be also suggested for compounds 6a and 8a. Conversely, the absence of activity in the analogs 6 and $\mathbf{8}$ could be due to kinetic factors including degradation processes or the inability to reach the potential targets.

\subsection{Synthesis of Oxylipin Analogues and Evaluation of Inhibitory Activity on Development of Sea-Urchin Embryos}

Considering the inherent chemical instability of the polyunsaturated chain and the biological effects of compounds $6 \mathbf{a}$ and $\mathbf{8 a}$, we synthesized a number of analogs containing a rational combination of the oxygenated functions found in natural oxylipins. Preliminarily, using oleic acid as starting material, a synthetic strategy was designed in order to have access to different types of C18-compounds (Scheme 2). To this aim, allylic oxidation of oleic acid methyl ester by copper (I) iodide and $t$-butyl hydroperoxide [17] yielded the mixture of $\alpha, \beta$-unsaturated keto regioisomers 11a and 11b. The following reduction by DIBAL in THF gave the regioisomers mixture $\mathbf{1 2}$ of enol derivatives that was further oxidized to the isomeric epoxy-alcohols 13 by 3-chloroperoxybenzoic acid (MCPBA). In another reaction, the isomeric enones $\mathbf{1 1 a} / \mathbf{1 1 b}$ were acetylated giving rise to the corresponding enols 14 which were then oxidized at the allylic position by Oxone ${ }^{\circledR}$ [18] obtaining the regioisomeric mixture 15 that was further purified giving compounds $\mathbf{1 5 a}$ and $\mathbf{1 5 b}$. 
Scheme 2. Synthetic strategy for preparation of C18-analogs of diatom oxylipins.

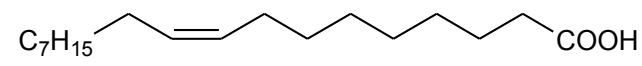

9.

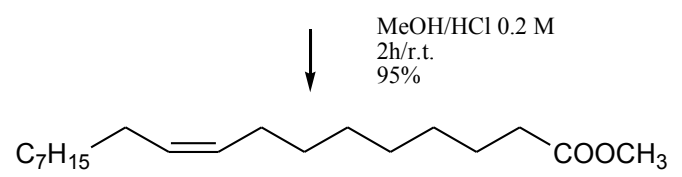

10.

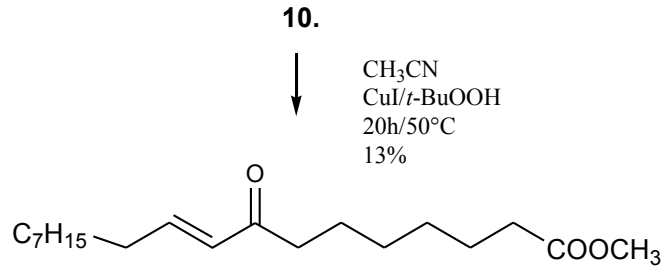

$11 \mathrm{a}$.

$+$

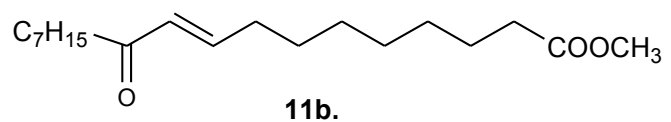

$11 \mathrm{~b}$.
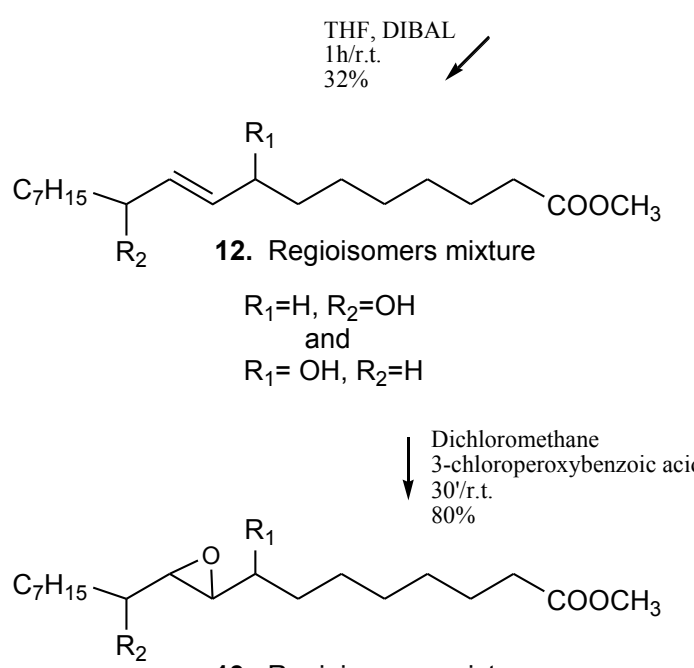

13. Regioisomers mixture

$$
\begin{gathered}
\mathrm{R}_{1}=\mathrm{H}, \mathrm{R}_{2}=\mathrm{OH} \\
\text { and } \\
\mathrm{R}_{1}=\mathrm{OH}, \mathrm{R}_{2}=\mathrm{H}
\end{gathered}
$$
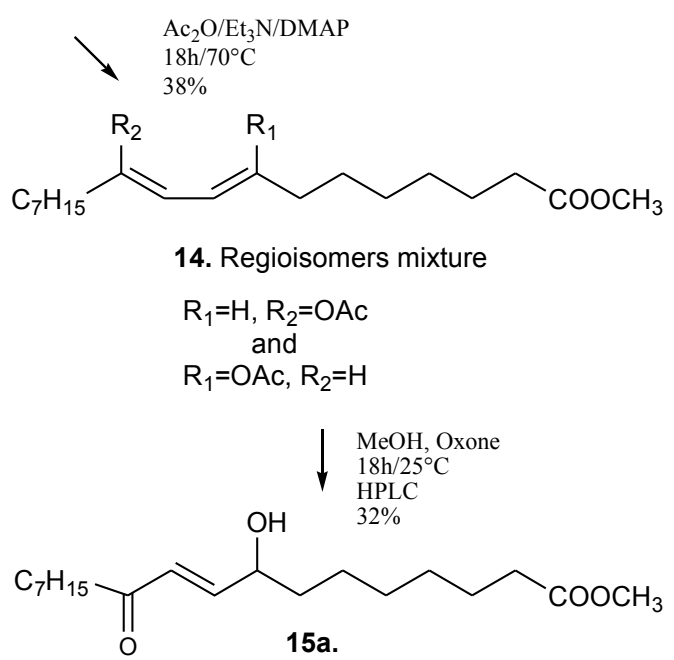

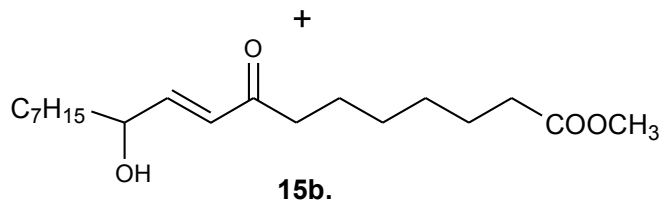

All these products were assessed for their ability to interfere with the development of sea urchin embryos. In agreement with the results on natural compounds, the synthetic products containing the free carboxylic function were not active (data not shown). The $\alpha, \beta$-unsatured keto-ester 11a gave the best results $($ IC50 $=28.0 \mu \mathrm{M})$ together with the corresponding ketols $\mathbf{1 5 a} / \mathbf{1 5 b}($ IC50 $=46.0 \mu \mathrm{M})$ (Figure 2a). 
Figure 2. Cleavage inhibition in sea urchin embryos treated with increasing concentrations of (a) $\mathrm{C}_{18}$-fatty acid synthetic derivatives and (b) synthetic $\mathrm{C}_{15}$-alkyl derivatives. Compound numbering is according to the structure reported in Schemes 2 and 3. Values (means \pm S.D.; $N=600$ ) are the results of three different experiments.

a)

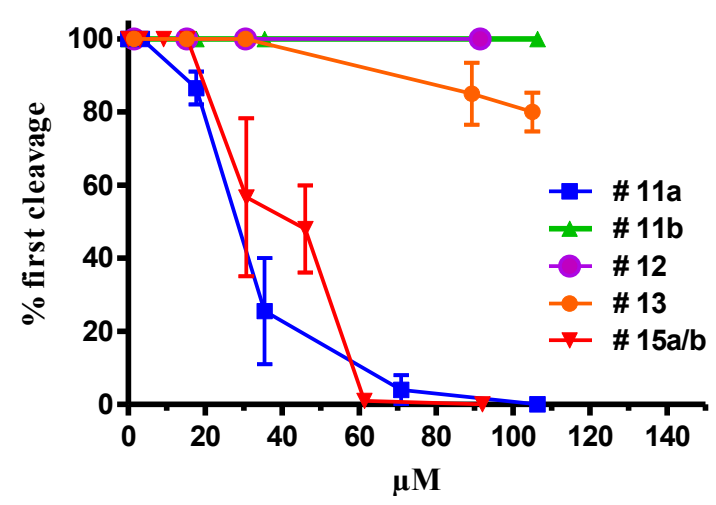

b)

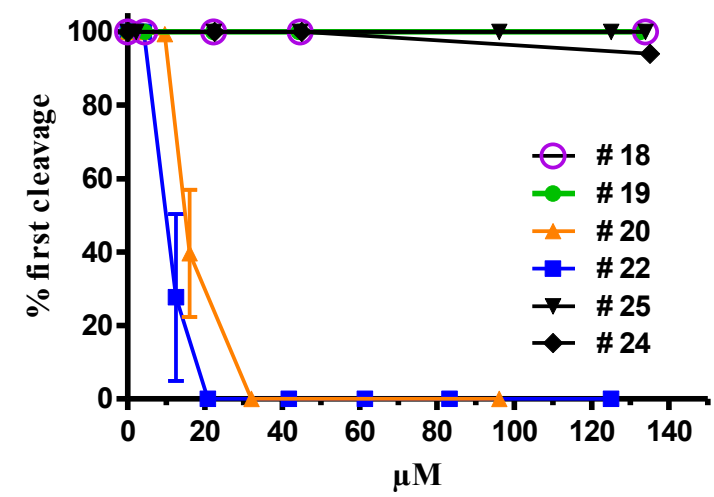

Scheme 3. Synthetic scheme for preparation of compounds 18-25.<smiles>[R]C/C=C\C=O</smiles><smiles>[R]C(=O)CP(=O)(OC)OC</smiles>

16. $\mathrm{R}_{1}=\mathrm{C}_{4} \mathrm{H}_{9}$ 23. $\mathrm{R}_{1}=\mathrm{C}_{4} \mathrm{H}_{9}, \Delta^{2,3}$ 17. $\mathrm{R}_{2}=\mathrm{C}_{5} \mathrm{H}_{11}$

$$
\downarrow \begin{aligned}
& \mathrm{CH}_{3} \mathrm{CN} \\
& \text { DIPEA/LiCl } \\
& 91 \%
\end{aligned}
$$<smiles>[R7]C/C=C/C=C/C([R2])=O</smiles>

18. $\mathrm{R}_{1}=\mathrm{C}_{4} \mathrm{H}_{9}, \mathrm{R}_{2}=\mathrm{C}_{5} \mathrm{H}_{11} \Delta^{7,8}$ 24. $\mathrm{R}_{1}=\mathrm{C}_{4} \mathrm{H}_{9}, \mathrm{R}_{2}=\mathrm{C}_{5} \mathrm{H}_{11}, \Delta^{7,8}, \Delta^{9,10}$

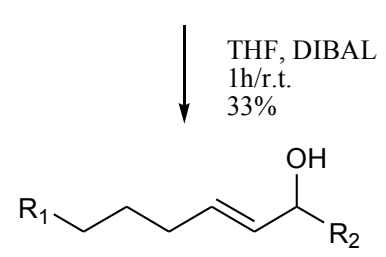

$$
\text { 19. } \mathrm{R}_{1}=\mathrm{C}_{4} \mathrm{H}_{9}, \mathrm{R}_{2}=\mathrm{C}_{5} \mathrm{H}_{11}
$$

Dichloromethane

3-chloroperoxybenzoic acid

$301 /$ r.t.

$92 \%$<smiles>[R7]CCCC1OC1C([R2])O</smiles>

20. $\mathrm{R}_{1}=\mathrm{C}_{4} \mathrm{H}_{9}, \mathrm{R}_{2}=\mathrm{C}_{5} \mathrm{H}_{11}$

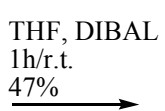<smiles>[R]C/C=C/C=C/C([R2])O</smiles>

25. $\mathrm{R}_{1}=\mathrm{C}_{4} \mathrm{H}_{9}, \mathrm{R}_{2}=\mathrm{C}_{5} \mathrm{H}_{11}$

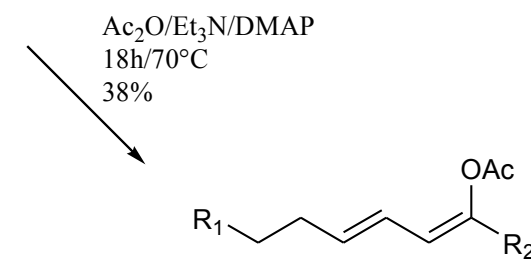

21. $\mathrm{R}_{1}=\mathrm{C}_{4} \mathrm{H}_{9}, \mathrm{R}_{2}=\mathrm{C}_{5} \mathrm{H}_{11}$

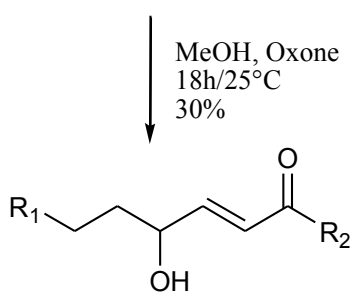

22. $\mathrm{R}_{1}=\mathrm{C}_{4} \mathrm{H}_{9}, \mathrm{R}_{2}=\mathrm{C}_{5} \mathrm{H}_{11}$ 
In agreement with the results obtained with natural oxylipins, the activity of these molecules suggested that the presence of the enone moiety (Michael acceptor) is directly related to the inhibition of development of sea urchin embryos. Introduction of the hydroxy group affected the electrophilicity of the enone, thus possibly explaining the difference in potency of 11a and the regioisomeric mixture $\mathbf{1 5 a} / \mathbf{1 5 b}$. Nevertheless, the significant difference between 11a and $\mathbf{1 1 b}$ activity after chromatographic purification, indicated that other structural features were also required to trigger the effect, thus corroborating the hypothesis that the mechanism of action of these molecules is due to interactions with specific cellular targets.

To further simplify the molecular scaffold and to increase the lipophilicity of the molecule, we prepared a second series of products without the carboxy group by using a combinatory approach that relies on olefination of two synthons by Horner-Wadsworth-Emmons reaction. The strategy is very versatile and has been used to prepare a large number of compounds starting from commercial reagents. Because the $\mathrm{C}_{16}$-compound $\mathbf{8 a}$ was significantly more potent than the analogous $\mathrm{C}_{18}$-products $11 \mathrm{a} / \mathbf{1 1 b}$, we focused on the preparation of molecules with shorter alkyl chains. As reported in Scheme 3, stable $\mathrm{C}_{15}$-derivatives containing ketol and enone functions were easily obtained by coupling of $\mathrm{C}_{8}$-aldehydes and dimethyl 2-oxoheptylphosphonate (16) with 17 . This way, the reaction of octanal led to the $\alpha, \beta$-keto-unsaturated compound $\mathbf{1 8}$ that quantitatively gave the enol derivative $\mathbf{1 9}$ by DIBAL reduction. This latter product could be easily transformed to the epoxyalcohol 20 by epoxydation with MCPBA. $\gamma$-Ketol 22 was obtained from 18 by acetylation and Oxone ${ }^{\circledR}$ oxidation. Analogously, dienone 24 and dienol 25 were obtained starting from octenal (23).

Activity of compounds 18-22 and 24-25 on sea urchin embryos is reported in Figure $2 b$. Surprisingly, compound $\mathbf{1 8}$ that showed the closest analogy with the methyl ester of the natural compound 8a (IC50 =6 $\mu \mathrm{M})$ was totally ineffective in inhibiting the development of the embryos. On the contrary, the epoxyalcohol 20 and the ketol 22 drastically reduced the percentage of dividing embryos. The latter compound showed an IC50 of $10 \mu \mathrm{M}$ that was close to the value found with the natural compound $\mathbf{8 a}$.

\subsection{Apoptotic Activity of Compound 22}

In analogy with the effect of exposure to high concentrations of natural oxylipins [2,14], sea urchin embryos treated with compound 22 revealed a dose-dependent increase in bleb formation. Because this effect had been previously associated with apoptosis [14], we studied the response of embryos to ketol 22 by terminal deoxynucleotidyl transferase (TdT) dUTP Nick-End Labeling (TUNEL) assay that is routinely used to detect extensive DNA degradation during the late stages of apoptosis. Confocal images of the sea urchin embryos treated with 22 at $10 \mu \mathrm{M}$ clearly revealed that some of the nuclei were intensely fluorescent in agreement with the onset of the DNA degradation (Figure 3), as already reported with pro-apoptotic aldehydes produced by diatoms [14]. Other cells showed barely stained nuclei due to progression of DNA degradation with consequent reduction and diffusion of nuclear material. In addition, the occurrence of blebbing vesicles was clearly visible (Figure 3b, arrowhead). 
Figure 3. Z-projections of confocal images of sea urchin eggs stained with TUNEL 70 min after fertilization: (a) control and (b) eggs treated with $10 \mu \mathrm{M}$ of 22. Arrows indicate positive nuclei that appear fluorescent and arrowhead indicates blebbing on egg surface.

(a)

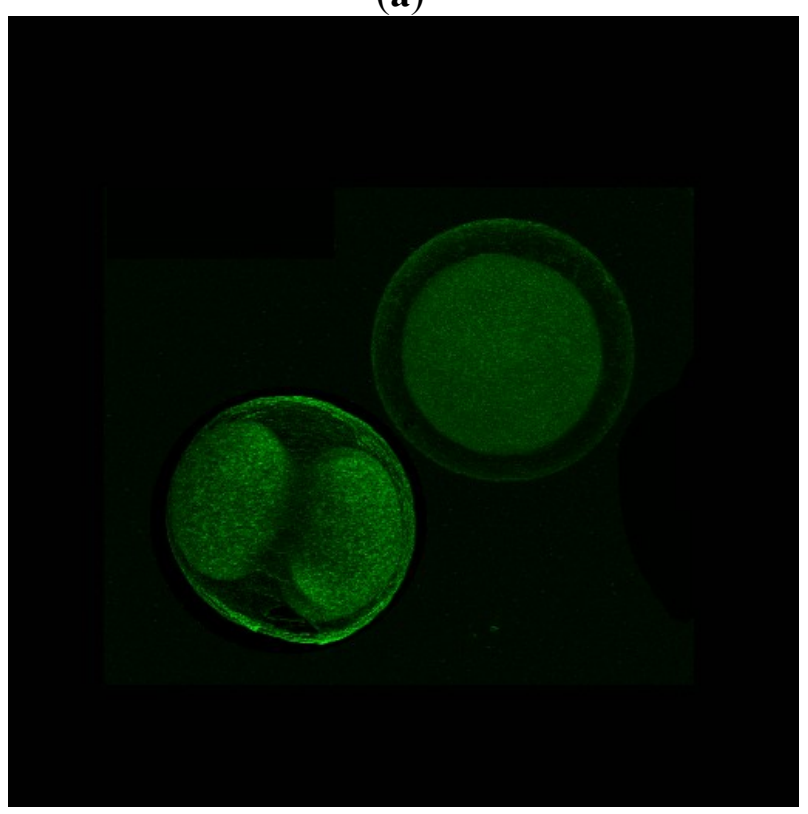

(b)

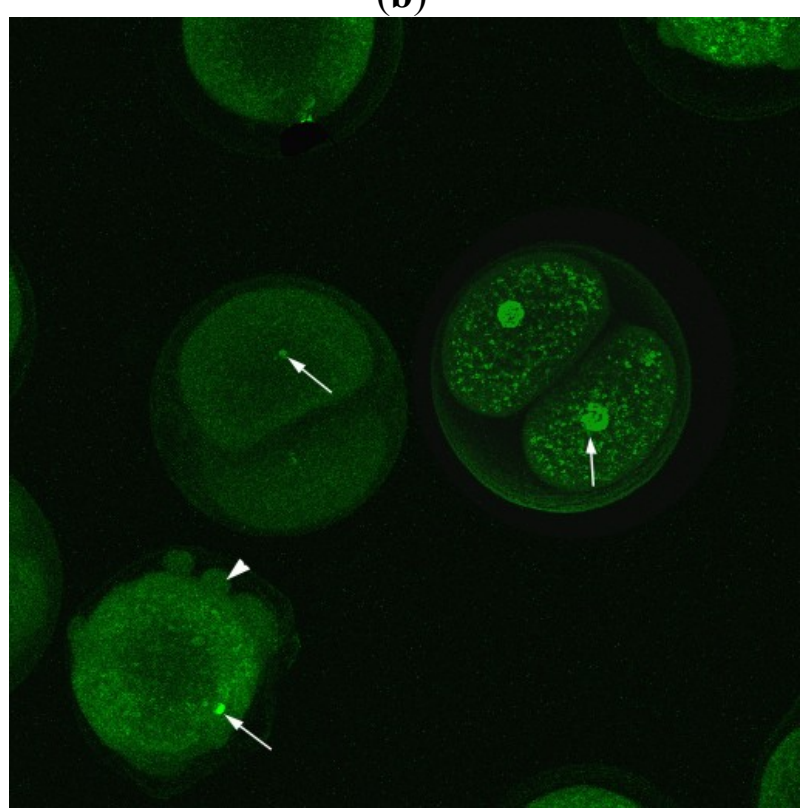

To determine whether compound 22 induced apoptosis in tumor cell lines, U-937 cells were incubated with increasing concentrations of the synthetic product. This cell line was selected on the basis of its resistance to apoptotic stimuli determined in previous studies [19]. As reported in Figure 4, the ketol 22 showed a dose-dependent cytotoxicity with an apparent EC50 of about $19 \mu \mathrm{M}$.

Figure 4. Compound 22 is cytotoxic in U-937 cell line. Cells were treated with different doses of 22, as indicated. Cytotoxicity was measured by neutral red assay and reported as a percentage of DMSO treated control cells, as described in Methods. Data points represent the mean of three experiments $( \pm$ S.E.).

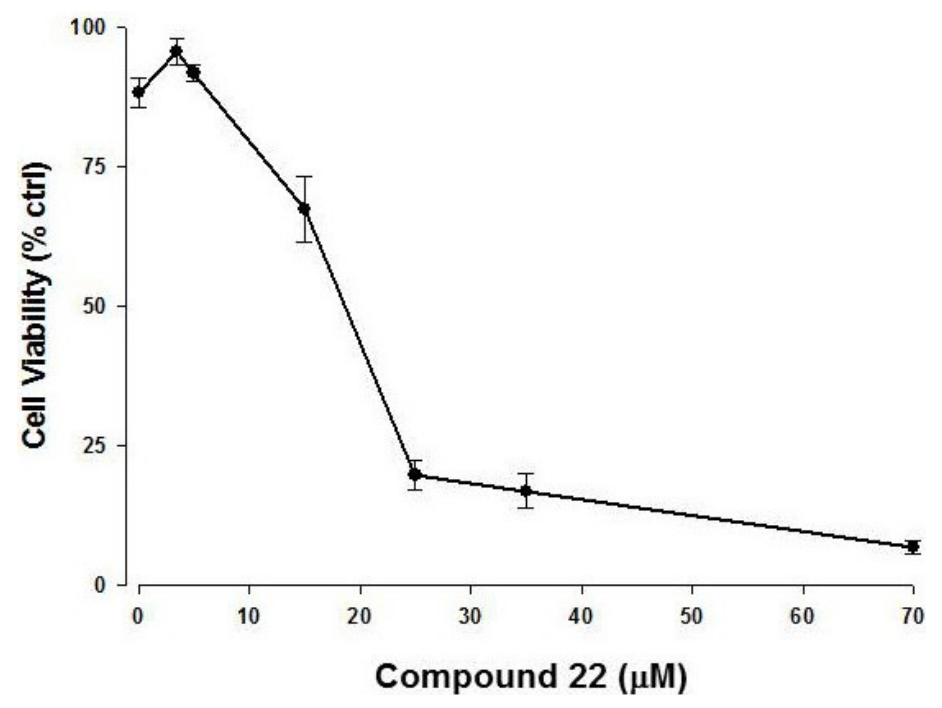


To determine the mechanism leading to cell death and to discriminate between induction of necrotic or apoptotic processes, cells treated with 22 were stained with Annexin-V to detect Phosphatidylserine (PS) externalization, as a marker of an active apoptotic process. At $25 \mu \mathrm{M}, 22$ efficiently induced apoptosis as demonstrated by the coincidence between the population of Annexin- $\mathrm{V}$ positive cells and the total population of dead cells (Figure 5a). Nevertheless, at higher concentrations (above $35 \mu \mathrm{M}$ ) a prevalence of a necrotic process was observed, as indicated by the high positivity to propidium iodide staining with respect to Annexin-V (Figure $5 b$ ).

Figure 5. Compound 22 induces apoptosis in U-937 cell line. (a) Cells were treated with 22 at the concentrations indicated for $24 \mathrm{~h}$. Apoptosis was quantified by Annexin V-FITC staining, measured with flow cytometry, and normalized with respect to controls treated with DMSO. Bars A+ indicate positivity to Annexin V, while bars $\mathrm{A}+\mathrm{P}+$ indicate positivity to Annexin $\mathrm{V}$ and propidium iodide. (b) Proteolytic activities of caspases-3 was measured after 6 and $24 \mathrm{~h}$ and reported as -fold increase with respect to DMSO-treated cells. In panel (b), bars represent the mean of three experiments $( \pm$ S.E. $)$. Symbols indicate significance: $p<0.01(*)$ with respect to DMSO-treated samples; $p<0.001(* *)$.

a)

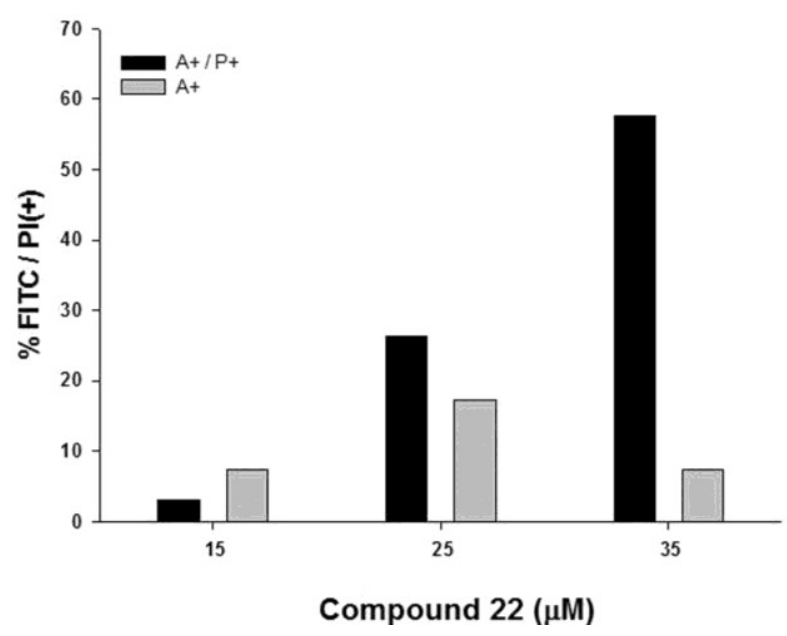

b)

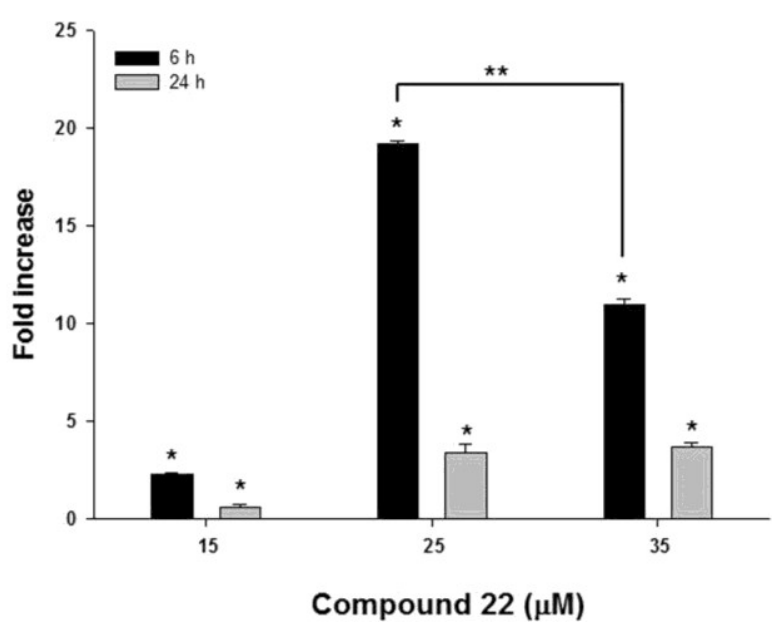

The same trend was confirmed by the determination of caspase- 3 activity, a hallmark of apoptotic induction in several cellular models. Compound 22 induced about a 20 -fold increase in caspase-3 activity after only $6 \mathrm{~h}$. After $24 \mathrm{~h}$, although caspase-3 activity remained higher compared to controls, its enzymatic activity was significantly reduced in comparison with the beginning of the experiments, thus indicating the presence of secondary apoptotic events and/or necrotic cell death (Figure 5b). According to these data it is reasonable to suggest that ketol 22 induces apoptosis by activation of specific cell mechanisms (e.g., caspase-3 in leukemia-derived U-937 cells) at low concentrations, whereas it is responsible for general cytotoxicity at higher concentrations. Further studies are necessary to evaluate the pro-apoptotic activity of active diatom oxylipins that inspired the synthesis of compound 22.

Inhibition of cell division, apoptotic and necrotic cell degradations by other Michael acceptors, such as the model short chain aldehyde $2 E, 4 E$-decadienal, have already been reported in experiments performed in vitro and in vivo [14,20-22]. On the contrary, studies on non-volatile oxylipin activity are 
still scarce. In this context, the ketol 22 could be used as a model compound to unravel the molecular mechanisms of oxylipin action in different biological systems.

\section{Experimental Section}

1D- and 2D-NMR spectra were recorded on a Bruker Avance-400 (400.13 MHz) and on a Bruker DRX-600 equipped with a TXI CryoProbe in $\mathrm{CDCl}_{3}$ and $\mathrm{C}_{6} \mathrm{D}_{6}$ ( $\delta$ values are referred to $\mathrm{CHCl}_{3}$ and $\mathrm{C}_{6} \mathrm{HD}_{5}$ at 7.26 and $7.16 \mathrm{ppm}$, respectively) and ${ }^{13} \mathrm{C}$ NMR spectra were recorded on a Bruker DPX-300 $\left(75.47 \mathrm{MHz}\right.$ ) ( $\delta$ values are referred to $\mathrm{CDCl}_{3}$ and $\mathrm{C}_{6} \mathrm{D}_{6}$ at 77.0 and $128.0 \mathrm{ppm}$ respectively). HRESI $^{+}$-MS was measured on a Micromass Q-TOF micro. TLC plates (Kieselgel $60 \mathrm{~F}_{254}$ ) and silica gel powder (Kieselgel 60, 0.063-0.200 mm) were from Merck (Merck and Co., Darmstadt, Germany).

All the reagents were purchased from Sigma-Aldrich (Milan, Italy) and used without any further purification.

All the synthetic intermediates were characterized by MS and NMR analysis.

\subsection{Chemical Synthesis of Oxylipin Analogues}

Compounds 11a and 11b: Following the procedure of Salvador et al. [17] oleic acid methylester (10, $1 \mathrm{~g}, 3.5 \mathrm{mmol})$ was dissolved in acetonitrile $(18 \mathrm{~mL})$ under argon; copper (I) iodide $(6.8 \mathrm{mg}$, $0.035 \mathrm{mmol})$ and t-butylhydroperoxide $(4.16 \mathrm{~mL}, 23 \mathrm{mmol})$ were added; the reaction mixture was stirred at $50{ }^{\circ} \mathrm{C}$ for $20 \mathrm{~h}$. Subsequently the solution was poured into sodium sulfite solution (10\% aq.) and extracted with diethyl ether; the extract was washed with aq. saturated solution of $\mathrm{NaHCO}_{3}$, brine and water, dried $\left(\mathrm{MgSO}_{4}\right)$, evaporated to dryness and was purified by silica-gel column using a gradient of petroleum ether and diethylether to give $\mathbf{1 1}$ as a mixture of regioisomers (140 $\mathrm{mg}$, $0.45 \mathrm{mmol}, 13 \%) ; \mathrm{R}_{f}$ (Petroleum ether/diethyl ether 7:3) $=0.53 ;{ }^{1} \mathrm{H}-\mathrm{NMR}\left(400 \mathrm{MHz}, \mathrm{C}_{6} \mathrm{D}_{6}\right)$ : $\delta=6.66(\mathrm{dt}, J=15.7,6.4 \mathrm{~Hz}, 1 \mathrm{H}), 6.01(\mathrm{bd}, J=15.7 \mathrm{~Hz}, 1 \mathrm{H}), 3.38\left(\mathrm{~s}, 3 \mathrm{H} ; \mathrm{OCH}_{3}\right), 2.29(\mathrm{t}, J=7.4$, 2H), $2.08\left(\mathrm{t}, J=7.4 \mathrm{~Hz}, 2 \mathrm{H} ; \mathrm{H}_{2} 2\right), 1.81(\mathrm{~m}, 2 \mathrm{H}), 1.54(\mathrm{~m}, 2 \mathrm{H}), 1.32-1.15(\mathrm{~m}, 20 \mathrm{H}), 0.89$ (t, $J=6.5$, $\left.3 \mathrm{H} ; \mathrm{H}_{3} 18\right)$; UV $\lambda_{\max }(\mathrm{MeOH}) 219 \mathrm{~nm}(\varepsilon=4401)$; HRMS $\left(\mathrm{ESI}^{+}\right): m / z$ calcd for $\mathrm{C}_{19} \mathrm{H}_{34} \mathrm{O}_{3} \mathrm{Na}: 333.2406$; found: 333.2411; part of mixture $11(10 \mathrm{mg}$ ) was purified on direct-phase HPLC ( $n$-hexane/AcOEt $92 / 8$, flow rate $2 \mathrm{~mL} / \mathrm{min}$ ) to afford $\mathbf{1 1 a}(4 \mathrm{mg}$ ) and $\mathbf{1 1 b}(3 \mathrm{mg})$. The compounds were characterized by NMR, and in particular 2D-TOCSY, was diagnostic to distinguish two spin systems.

Mixture 12: mixture $11(70 \mathrm{mg}, 0.23 \mathrm{mmol})$ was dissolved in fresh distilled THF $(1.0 \mathrm{~mL})$ and $0.17 \mathrm{~mL}$ of diisobutylaluminium hydride solution in THF $(1 \mathrm{M})$ were drop-wise added at $0{ }^{\circ} \mathrm{C}$ and the mixture was stirred at room temperature for $1 \mathrm{~h}$ and after was partitioned between water and diethylether; the organic phase was purified by silica-gel column using a gradient of petroleum ether and diethylether to give 12 (22 mg, $0.074 \mathrm{mmol}, 32 \%)$; $\mathrm{R}_{f}$ (Petroleum ether/diethyl ether 7:3) = 0.22; ${ }^{1} \mathrm{H}-\mathrm{NMR}\left(400 \mathrm{MHz}, \mathrm{C}_{6} \mathrm{D}_{6}\right): \delta=5.50(\mathrm{dd}, J=15.9,6.0 \mathrm{~Hz}, 1 \mathrm{H}), 5.44(\mathrm{dt}, J=15.9,5.5 \mathrm{~Hz}, 1 \mathrm{H})$, $3.94(\mathrm{~m}, 1 \mathrm{H}), 3.38\left(\mathrm{~s}, 3 \mathrm{H}, \mathrm{OCH}_{3}\right), 2.10\left(\mathrm{t}, J=7.1 \mathrm{~Hz}, 2 \mathrm{H} ; \mathrm{H}_{2} 2\right), 1.95(\mathrm{~m}, 2 \mathrm{H}), 1.69-1.25(\mathrm{~m}, 22 \mathrm{H})$, $0.90\left(\mathrm{t}, J=6.6,3 \mathrm{H} ; \mathrm{H}_{3} 18\right)$. HRMS $\left(\mathrm{ESI}^{+}\right): \mathrm{m} / z$ calculated for $\mathrm{C}_{19} \mathrm{H}_{36} \mathrm{O}_{3} \mathrm{Na}$ : 335.2512; found: 335.2517 .

Mixture 13: mixture $12(20 \mathrm{mg}, 0.067 \mathrm{mmol})$ was dissolved in anhydrous dichloromethane $(5 \mathrm{~mL})$ and $150 \mathrm{mg}$ of 3-chloroperoxybenzoic acid (MCPBA, purity $\leq 77 \%$ ) dissolved in $3 \mathrm{~mL}$ of anhydrous dichloromethane was added drop-wise at $0{ }^{\circ} \mathrm{C}$; the mixture was stirred for $30 \mathrm{~min}$ and purified by 
silica-gel column using a gradient of petroleum ether and diethylether to give $\mathbf{1 3}$ as a mixture of regioisomers (18 mg, $0.054 \mathrm{mmol}, 80 \%$ ); $\mathrm{R}_{f}$ (Petroleum ether/diethyl ether 6/4) $=0.1$; ${ }^{1} \mathrm{H}-\mathrm{NMR}$ $\left(400 \mathrm{MHz}, \mathrm{C}_{6} \mathrm{D}_{6}\right): \delta=3.36\left(\mathrm{~s}, 3 \mathrm{H} ; \mathrm{OCH}_{3}\right), 3.29(\mathrm{~m}, 1 \mathrm{H}), 2.73(\mathrm{~m}, 1 \mathrm{H}), 2.54(\mathrm{~m}, 1 \mathrm{H}), 2.09$ (t, $\left.J=7.5 \mathrm{~Hz}, 2 \mathrm{H} ; \mathrm{H}_{2} 2\right), 1.73-1.20(\mathrm{~m}, 24 \mathrm{H}), 0.90\left(\mathrm{t}, J=6.2,3 \mathrm{H} ; \mathrm{H}_{3} 18\right)$. HRMS $\left(\mathrm{ESI}^{+}\right): \mathrm{m} / z$ calcd for $\mathrm{C}_{19} \mathrm{H}_{36} \mathrm{O}_{4} \mathrm{Na}$ : 351.2512; found: 351.2507 .

Mixture of Compounds 15a and 15b: Mixture $11(70 \mathrm{mg}, 0.23 \mathrm{mmol}), N, N$-dimethylaminopyridine $(3.1 \mathrm{mg}, 0.025 \mathrm{mmol})$, triethylamine $(0.051 \mathrm{~g}, 0.51 \mathrm{mmol})$ and acetic anhydride $(0.126 \mathrm{~g}, 1.26 \mathrm{mmol})$ were stirred for $18 \mathrm{~h}$ at $70{ }^{\circ} \mathrm{C}$; the mixture was partitioned between diethylether and ammonium bicarbonate $(10 \%)$ and the organic phase was purified by silica-gel column using a gradient of petroleum ether/diethylether to obtain the acetate intermediate $\mathbf{1 4}$ [18], that was dissolved in methanol $(0.5 \mathrm{~mL})$ and sodium bicarbonate (saturated) buffer solution $(0.5 \mathrm{~mL})$ of Oxone ${ }^{\circledR}(0.052 \mathrm{mmol})$; after stirring at $25^{\circ} \mathrm{C}$ for $7 \mathrm{~h}$, methanol $(0.5 \mathrm{~mL})$, water $(0.5 \mathrm{~mL})$ and oxone $(0.052 \mathrm{mmol})$ were added and the mixture was kept under stirring overnight; after partition between water and chloroform, the organic phase was purified by silica-gel column using a gradient of petroleum ether and diethylether to give 15 as a mixture of regioisomers $(9 \mathrm{mg}, 0.0276 \mathrm{mmol}, 12 \%) ; \mathrm{R}_{f}$ (Petroleum ether/diethyl ether $6 / 4)=0.1 ;{ }^{1} \mathrm{H}-\mathrm{NMR}\left(400 \mathrm{MHz}, \mathrm{C}_{6} \mathrm{D}_{6}\right): \delta=6.64(\mathrm{dd}, J=15.7,4.5 \mathrm{~Hz}, 1 \mathrm{H}), 6.23(\mathrm{dd}, J=15.7,1.4 \mathrm{~Hz}$, $1 \mathrm{H}), 3.79(\mathrm{~m}, 1 \mathrm{H}), 3.39\left(\mathrm{~s}, 3 \mathrm{H} ; \mathrm{OCH}_{3}\right), 2.28(\mathrm{t}, J=7.2 \mathrm{~Hz}, 2 \mathrm{H}), 2.06(\mathrm{t}, J=7.2 \mathrm{~Hz}, 2 \mathrm{H} ; \mathrm{H} 2), 1.69$ (m, $2 \mathrm{H}), 1.51(\mathrm{~m}, 2 \mathrm{H}), 1.30-1.11(\mathrm{~m}, 16 \mathrm{H}), 0.89\left(\mathrm{t}, J=6.2,3 \mathrm{H} ; \mathrm{H}_{3} 18\right) ;{ }^{13} \mathrm{C}-\mathrm{NMR}\left(100 \mathrm{MHz}, \mathrm{C}_{6} \mathrm{D}_{6}\right)$ : $\delta=199.2(\mathrm{C}), 147.2(\mathrm{CH}), 128.0(\mathrm{CH}), 70.9(\mathrm{CH}), 51.0\left(\mathrm{OCH}_{3}\right), 41.03\left(\mathrm{CH}_{2}\right), 36.7\left(\mathrm{CH}_{2}\right), 33.9\left(\mathrm{CH}_{2}\right)$, $32.1\left(\mathrm{CH}_{2}\right), 30.3\left(\mathrm{CH}_{2}\right), 29.8\left(\mathrm{CH}_{2}\right), 29.6\left(\mathrm{CH}_{2}\right), 29.1\left(\mathrm{CH}_{2}\right), 25.1\left(2 \mathrm{CH}_{2}\right), 24.4\left(\mathrm{CH}_{2}\right), 23.0\left(\mathrm{CH}_{2}\right)$, $14.3\left(\mathrm{CH}_{3}\right)$. UV $\lambda_{\max }(\mathrm{MeOH}) 219 \mathrm{~nm}(\varepsilon=1570)$; HRMS $\left(\mathrm{ESI}^{+}\right): m / z$ calcd for $\mathrm{C}_{19} \mathrm{H}_{34} \mathrm{O}_{4} \mathrm{Na}: 349.2355$; found: 349.2359. Mixture 15 was purified on reverse-phase HPLC (methanol/water gradient 6/4 until 9/1, flow rate $2.5 \mathrm{~mL} / \mathrm{min})$ to afford $\mathbf{1 5 a}(3 \mathrm{mg})$ and $\mathbf{1 5 b}(5 \mathrm{mg})$.

Compound 18: Dimethyl 2-oxoheptylphosphonate (17, $2.67 \mathrm{~g}, 12 \mathrm{mmol}), N, N$-diisopropylethylamine $(1.29 \mathrm{~g}, 10 \mathrm{mmol})$ and octanal $(\mathbf{1 6}, 1.28 \mathrm{~g}, 10 \mathrm{mmol})$ were added to a solution of lithium chloride $(0.50 \mathrm{~g}, 12 \mathrm{mmol})$ in acetonitrile $(120 \mathrm{~mL})$ under argon; after stirring for $3 \mathrm{~h}$ the reaction mixture was evaporated and purified by silica-gel column using a gradient of petroleum ether/diethylether gradient to give 18 (2.01 g, $9.1 \mathrm{mmol}, 91 \%)$ [23]: $\mathrm{R}_{f}$ (Petroleum ether/diethyl ether 95:5) $=0.52 ;{ }^{1} \mathrm{H}-\mathrm{NMR}$ $\left(400 \mathrm{MHz}, \mathrm{C}_{6} \mathrm{D}_{6}\right): \delta=6.62(\mathrm{dt}, J=15.7,6.7 \mathrm{~Hz}, 1 \mathrm{H} ; \mathrm{H} 6), 5.93$ (bd, $\left.J=15.7 \mathrm{~Hz}, 1 \mathrm{H} ; \mathrm{H} 7\right), 2.29$ (t, $\left.J=7.4,2 \mathrm{H} ; \mathrm{H}_{2} 9\right), 1.99\left(\mathrm{~m}, 2 \mathrm{H} ; \mathrm{H}_{2} 5\right), 1.52(\mathrm{~m}, 2 \mathrm{H}), 1.30-1.15(\mathrm{~m}, 14 \mathrm{H}), 0.81\left(\mathrm{t}, J=6.2,6 \mathrm{H} ; \mathrm{H}_{3} 1\right.$, $\left.\mathrm{H}_{3} 15\right) ;{ }^{13} \mathrm{C}-\mathrm{NMR}\left(100 \mathrm{MHz}, \mathrm{C}_{6} \mathrm{D}_{6}\right): \delta=198.3(\mathrm{C} 8, \mathrm{C}), 145.9(\mathrm{C} 6, \mathrm{CH}), 130.8(\mathrm{C} 7, \mathrm{CH}), 40.1(\mathrm{C} 9$, $\left.\mathrm{CH}_{2}\right)$, $32.6\left(\mathrm{CH}_{2}\right), 32.1\left(2 \mathrm{CH}_{2}\right), 29.6\left(2 \mathrm{CH}_{2}\right), 29.5\left(\mathrm{CH}_{2}\right), 24.2\left(\mathrm{CH}_{2}\right), 23.0\left(2 \mathrm{CH}_{2}\right), 14.3\left(2 \mathrm{CH}_{3}\right)$. HRMS (ESI $\left.{ }^{+}\right): m / z$ calcd for $\mathrm{C}_{15} \mathrm{H}_{28} \mathrm{ONa}$ : 247.2038; found: 247.2033.

Compound 19: Ketone $18(0.06 \mathrm{~g}, 0.25 \mathrm{mmol})$ was dissolved in fresh distilled tetrahydrofurane $(1 \mathrm{~mL})$ and $0.150 \mathrm{~mL}$ of diisobutylaluminium hydride solution in THF $(1 \mathrm{M})$ were drop-wise added at $-5{ }^{\circ} \mathrm{C}$; after $1 \mathrm{~h}$ of stirring, other $0.015 \mathrm{~mL}$ of DIBAL solution in THF $(1 \mathrm{M})$ were added; after $1 \mathrm{~h}$ the mixture was partitioned between water and diethylether; the organic phase was purified by silica-gel column using a gradient of petroleum ether and diethylether to give 19 (0.02 g, $0.08 \mathrm{mmol}$, $33 \%) ; \mathrm{R}_{f}$ (Petroleum ether/diethyl ether 95:5) $=0.12 ;{ }^{1} \mathrm{H}-\mathrm{NMR}\left(400 \mathrm{MHz}, \mathrm{C}_{6} \mathrm{D}_{6}\right): \delta=5.54$ (dt, $J=15.5,6.4 \mathrm{~Hz}, 1 \mathrm{H} ; \mathrm{H} 8), 5.43$ (dd, $J=15.5,6.2 \mathrm{~Hz}, 1 \mathrm{H} ; \mathrm{H} 7), 3.94$ (m, 1H; H6), 1.99 (m, 2H; H 29 ), 1.55-1.20. (m, 18H), 0.89 (t, $\left.J=6.4,6 \mathrm{H} ; \mathrm{H}_{3} 1, \mathrm{H}_{3} 15\right) ;{ }^{13} \mathrm{C}-\mathrm{NMR}\left(100 \mathrm{MHz}, \mathrm{C}_{6} \mathrm{D}_{6}\right): \delta=134.2(\mathrm{CH})$, 
131.2 (CH), $73.0(\mathrm{C} 6, \mathrm{CH}) 37.9\left(\mathrm{CH}_{2}\right), 32.6\left(\mathrm{CH}_{2}\right), 32.3\left(2 \mathrm{CH}_{2}\right), 30.0\left(\mathrm{CH}_{2}\right), 29.8\left(\mathrm{CH}_{2}\right), 29.5\left(\mathrm{CH}_{2}\right)$, $25.6\left(\mathrm{CH}_{2}\right), 23.1\left(2 \mathrm{CH}_{2}\right), 14.3\left(2 \mathrm{CH}_{3}\right)$.

$\mathrm{UV} \lambda_{\max }(\mathrm{MeOH}) 220 \mathrm{~nm}(\varepsilon=1295)$; HRMS (ESI): $m / z$ calcd for $\mathrm{C}_{15} \mathrm{H}_{30} \mathrm{ONa}$ : 249.2195; found: 249.2199 .

Compound 20: Alcohol $19(20 \mathrm{mg}, 0.08 \mathrm{mmol})$ was dissolved in anhydrous dichloromethane $(1.5 \mathrm{~mL})$ and 3-chloroperoxybenzoic acid $(50 \mathrm{mg})$ dissolved in $1 \mathrm{~mL}$ of anhydrous dichloromethane was added drop-wise at $0{ }^{\circ} \mathrm{C}$; the mixture was stirred for $30 \mathrm{~min}$ and purified by silica-gel column using a gradient of petroleum ether and diethylether to give 20 (18 $\mathrm{mg}, 0.074 \mathrm{mmol}, 92 \%)$; $\mathrm{R}_{f}($ Petroleum ether/diethyl ether $8 / 2)=0.25 ;{ }^{1} \mathrm{H}-\mathrm{NMR}\left(400 \mathrm{MHz}, \mathrm{C}_{6} \mathrm{D}_{6}\right): \delta=3.29(\mathrm{~m}, 1 \mathrm{H}), 2.73(\mathrm{~m}$, $1 \mathrm{H}), 2.54(\mathrm{~m}, 1 \mathrm{H}), 1.62-1.20(\mathrm{~m}, 20 \mathrm{H}), 0.88\left(\mathrm{t}, J=6.7,6 \mathrm{H} ; \mathrm{H}_{3} 1, \mathrm{H}_{3} 15\right)$. HRMS (ESI $\left.{ }^{+}\right): m / z$ calcd for $\mathrm{C}_{15} \mathrm{H}_{30} \mathrm{O}_{2} \mathrm{Na}$ : 265.2144; found: 265.2141.

Compound 22: Ketone 18 (0.97 g, $4.4 \mathrm{mmol}), N, N$-dimethylaminopyridine (58 mg, $0.48 \mathrm{mmol}$ ), triethylamine $(0.98 \mathrm{~g}, 9.7 \mathrm{mmol})$ and acetic anhydride $(2.4 \mathrm{~g}, 24 \mathrm{mmol})$ were stirred for $18 \mathrm{~h}$ at $70{ }^{\circ} \mathrm{C}$; the mixture was partitioned between diethylether and ammonium bicarbonate $(10 \%)$ and the organic phase was purified by silica-gel column using a gradient of petroleum ether/diethylether to obtain the acetate intermediate $21,(0.44 \mathrm{~g}, 1.654 \mathrm{mmol})$ that was dissolved in methanol $(3 \mathrm{~mL})$ and sodium bicarbonate (saturated) buffer solution $(2 \mathrm{~mL})$ of oxone $(1 \mathrm{mmol})$; after stirring at $25{ }^{\circ} \mathrm{C}$ for $7 \mathrm{~h}$, methanol $(2 \mathrm{~mL})$, water $(2 \mathrm{~mL})$ and oxone $(1 \mathrm{mmol})$ were added and the mixture was kept under stirring overnight; after partition between water and chloroform, the organic phase was purified by silica-gel column using a gradient of petroleum ether and diethylether to give $22(0.120 \mathrm{~g}, 0.5 \mathrm{mmol}$, $10 \%$ ) [18]. $\mathrm{R}_{f}$ (Petroleum ether/diethyl ether 95:5) $=0.1 ;{ }^{1} \mathrm{H}-\mathrm{NMR}\left(400 \mathrm{MHz}, \mathrm{C}_{6} \mathrm{D}_{6}\right): \delta=6.68$ (dd, $J=15.6,5.3 \mathrm{~Hz}, 1 \mathrm{H} ; \mathrm{H} 8), 6.25$ (dd, $J=15.6,1.2 \mathrm{~Hz}, 1 \mathrm{H} ; \mathrm{H} 7), 3.86$ (m, 1H; H9), 2.25 (t, $\left.J=7.2 \mathrm{~Hz}, 2 \mathrm{H} ; \mathrm{H}_{2} 5\right), 1.62(\mathrm{~m}, 2 \mathrm{H}), 1.35-1.18(\mathrm{~m}, 16 \mathrm{H}), 0.90\left(\mathrm{t}, J=6.4,6 \mathrm{H} ; \mathrm{H}_{3} 1, \mathrm{H}_{3} 15\right) ;{ }^{13} \mathrm{C}-\mathrm{NMR}$ $\left(100 \mathrm{MHz}, \mathrm{C}_{6} \mathrm{D}_{6}\right): \delta=199.0(\mathrm{C} 6, \mathrm{C}), 147.6(\mathrm{C} 8, \mathrm{CH}), 128.4(\mathrm{C} 7, \mathrm{CH}), 71.1(\mathrm{C} 9, \mathrm{CH}) 40.9\left(\mathrm{C}_{2}, \mathrm{CH}_{2}\right)$, $37.0\left(\mathrm{CH}_{2}\right), 32.0\left(\mathrm{CH}_{2}\right), 31.7\left(\mathrm{CH}_{2}\right), 29.5\left(\mathrm{CH}_{2}\right), 25.5\left(\mathrm{CH}_{2}\right), 24.0\left(\mathrm{CH}_{2}\right), 22.9\left(2 \mathrm{CH}_{2}\right), 14.2\left(2 \mathrm{CH}_{3}\right)$.

$\mathrm{UV} \lambda_{\max }(\mathrm{MeOH}) 219 \mathrm{~nm}(\varepsilon=12437)$; HRMS $\left(\mathrm{ESI}^{+}\right): m / z$ calcd for $\mathrm{C}_{15} \mathrm{H}_{28} \mathrm{O}_{2} \mathrm{Na}: 263.1987$; found: 263.1982 .

Compound 24: Starting from trans-2-octenal $(23,1 \mathrm{~g}, 8 \mathrm{mmol})$ and following the same procedure to get 18, compound 24 (1.60 g, $7.2 \mathrm{mmol}, 91 \%)$ was obtained; $\mathrm{R}_{f}$ (Petroleum ether/diethyl ether 95:5) $=0.42 ;{ }^{1} \mathrm{H}-\mathrm{NMR}\left(400 \mathrm{MHz}, \mathrm{C}_{6} \mathrm{D}_{6}\right): \delta=7.10(\mathrm{dd}, J=15.5,10.6 \mathrm{~Hz}, 1 \mathrm{H} ; \mathrm{H} 8), 5.99$ (d, $J=15.5 \mathrm{~Hz}, 1 \mathrm{H}$; H7), 5.96 (dd, $J=15.3,10.6 \mathrm{~Hz}, 1 \mathrm{H}$; H9), 5.82 (dt, $J=15.3,6.9 \mathrm{~Hz}, 1 \mathrm{H} ; \mathrm{H} 10), 2.31$ (t, $J=7.2 \mathrm{~Hz}, 2 \mathrm{H}$; $\left.\mathrm{H}_{2} 5\right), 1.94\left(\mathrm{~m}, 2 \mathrm{H} ; \mathrm{H}_{2} 11\right), 1.61(\mathrm{~m}, 2 \mathrm{H}), 1.29-1.13(\mathrm{~m}, 10 \mathrm{H}), 0.88$ (t, $\left.J=6.8 \mathrm{~Hz}, 6 \mathrm{H} ; \mathrm{H}_{3} 15, \mathrm{H}_{3} 1\right)$; ${ }^{13} \mathrm{C}-\mathrm{NMR}\left(100 \mathrm{MHz}, \mathrm{C}_{6} \mathrm{D}_{6}\right): \delta=198.8(\mathrm{C} 6, \mathrm{C}), 144.6(\mathrm{CH}), 142.1(\mathrm{CH}), 129.5(\mathrm{CH}), 128.6(\mathrm{CH})$, $40.9\left(\mathrm{CH}_{2}\right), 33.3\left(\mathrm{CH}_{2}\right), 31.9\left(\mathrm{CH}_{2}\right), 31.7\left(\mathrm{CH}_{2}\right), 28.8\left(\mathrm{CH}_{2}\right), 24.3\left(\mathrm{CH}_{2}\right), 22.9\left(\mathrm{CH}_{2}\right), 22.8\left(\mathrm{CH}_{2}\right), 14.2$ $\left(\mathrm{CH}_{3}\right), 14.2\left(\mathrm{CH}_{3}\right)$.

$\mathrm{UV} \lambda_{\max }(\mathrm{MeOH}) 264 \mathrm{~nm}(\varepsilon=1469)$; HRMS $\left(\mathrm{ESI}^{+}\right): m / z$ calcd for $\mathrm{C}_{15} \mathrm{H}_{26} \mathrm{ONa}$ : 245.1881; found: 245.1883 .

Compound 25: Unsaturated ketone $24(0.80 \mathrm{~g}, 3.6 \mathrm{mmol})$ was dissolved in fresh distilled $\mathrm{THF}$ $(8.0 \mathrm{~mL})$ and and $2.3 \mathrm{~mL}$ of diisobutylaluminium hydride solution in THF $(1 \mathrm{M})$ were added drop-wise at $-5{ }^{\circ} \mathrm{C}$; the mixture was stirred at room temperature for $1 \mathrm{~h}$ and after was partitioned between water 
and diethylether; the organic phase was purified by silica-gel column using a gradient of petroleum ether and diethylether to give 25 (0.39 g, $1.7 \mathrm{mmol}, 47 \%) ; \mathrm{R}_{f}$ (Petroleum ether/diethyl ether 95:5) $=0.16 ;{ }^{1} \mathrm{H}-\mathrm{NMR}\left(400 \mathrm{MHz}, \mathrm{C}_{6} \mathrm{D}_{6}\right): \delta=6.23-6.00(\mathrm{~m}, 2 \mathrm{H}), 5.69-5.00(\mathrm{~m}, 2 \mathrm{H}), 3.95(\mathrm{~m}, 1 \mathrm{H}$; H6), $2.00\left(\mathrm{~m}, 2 \mathrm{H} ; \mathrm{H}_{2} 11\right), 1.56-1.22(\mathrm{~m}, 14 \mathrm{H}), 0.87\left(\mathrm{t}, J=6.8 \mathrm{~Hz}, 6 \mathrm{H} ; \mathrm{H}_{3} 1, \mathrm{H}_{3} 15\right) ;{ }^{13} \mathrm{C}-\mathrm{NMR}$ $\left(100 \mathrm{MHz}, \mathrm{C}_{6} \mathrm{D}_{6}\right): \delta=134.8(\mathrm{CH}), 134.7(\mathrm{CH}), 130.8(\mathrm{CH}), 72.8(\mathrm{C} 6, \mathrm{CH}), 37.8\left(\mathrm{CH}_{2}\right), 30.1\left(\mathrm{CH}_{2}\right)$, $32.4\left(2 \mathrm{CH}_{2}\right), 29.8\left(2 \mathrm{CH}_{2}\right), 23.2\left(2 \mathrm{CH}_{2}\right), 14.3\left(2 \mathrm{CH}_{3}\right)$.

$\mathrm{UV} \lambda_{\max }(\mathrm{MeOH}) 230 \mathrm{~nm}(\varepsilon=9043)$; HRMS $\left(\mathrm{ESI}^{+}\right): m / z$ calcd for $\mathrm{C}_{15} \mathrm{H}_{28} \mathrm{ONa}$ : 247.2038; found: 247.2032 .

\subsection{Sea Urchin Gamete Collection}

Sea urchins Paracentrotus lividus (Lamarck) were collected during the breeding season by SCUBA diving in the Gulf of Naples and transported in an insulated box to the laboratory within one hour. Living organisms were injected with $0.2 \mathrm{~mL}$ of $0.2 \mathrm{M}$ acetylcholine (Sigma-Aldrich, Milan, Italy) to induce gamete ejection. Eggs were obtained from at least four females collected separately in beakers containing $0.22 \mu \mathrm{m}$ filtered sea water (FSW) in which they were allowed to settle. Egg suspensions were then washed three times and diluted with FSW to a final concentration of 3000 eggs $\mathrm{mL}^{-1}$. Sperm were collected dry as a mix from three males, stocked at $4{ }^{\circ} \mathrm{C}$ and diluted 1:10,000 just prior to fertilization. One hundred microliters of sperm suspension were added to $100 \mathrm{~mL}$ FSW containing egg suspension. Five minutes after sperm addition, the eggs were checked for successful fertilization and excess sperm were removed by washing the eggs with FSW.

\subsection{Antimitotic Assay on Sea Urchin Embryos}

Oxylipins were tested on sea urchin embryos assessing the effect on cell division (cleavage). Approximately 400 embryos were transferred soon after fertilization envelope elevation to tissue culture wells containing increasing concentrations of each oxylipin in $4 \mathrm{~mL}$ FSW. All concentrations were tested at least on three egg clutches collected from different females. Additional group of eggs from each female were used as controls. Embryos were kept at $20{ }^{\circ} \mathrm{C}$ in a controlled temperature chamber under 12:12 light:dark cycle. Effect of molecules on the first mitotic division was assessed circa 90 minutes after fertilization, when almost $100 \%$ of control embryos were at the two-blastomere stage. Cleavage inhibition was assessed by examining at least 200 embryos for each treatment under a light microscope (Axiovert 135TV, Carl Zeiss, Jena, Germany). Graphics from the experimental data and IC50 values were generated using the Prism software (GraphPad Software Inc., La Jolla, CA, USA).

\subsection{Tunel Fluorescence Labeling (TUNEL)}

Fertilization occurred in FSW with $1 \mathrm{mmol} \mathrm{L}^{-1}$ ATA (3-amino-1,2,4-triazole; Sigma-Aldrich, Milan, Italy) for immuno-fluorescence staining [14].

P. lividus embryos were fertilized in the presence of $1 \mathrm{mmol} \mathrm{L}^{-1}$ ATA (3-amino-1,2,4-triazole; Sigma-Aldrich, Milan, Italy) before incubation (see above) with 22 at $10 \mu \mathrm{M}$. After 90 min sea urchin embryos and controls were gently forced through a Pasteur pipette, to remove the fertilization envelop, rinsed three times in FSW, and fixed in paraformaldehyde 4\% (Sigma-Aldrich, Milan, Italy) in sea 
water for $2 \mathrm{~h}$ at room temperature. Fixed sea urchin embryos were washed several times in $10 \mathrm{mM}$ phosphate saline buffer at $\mathrm{pH} 7.4$ (PBS) to remove paraformaldehyde and then incubated for $30 \mathrm{~min}$, at $4{ }^{\circ} \mathrm{C}$, in a solution of $0.1 \%$ Triton X-100 and $0.1 \%$ sodium citrate. Apoptosis was assessed using TdT-mediated dUTP nick end labeling (TUNEL) (Roche Diagnostics, Milano, Italy) according to manufacturer's instructions. After washing in PBS containing $1 \%$ bovine albumin serum (BSA, Sigma-Aldrich, Milano, Italy), treated samples were incubated at $37^{\circ} \mathrm{C}$ for $90 \mathrm{~min}$ in TUNEL solution in a humidified chamber, in the dark. Control embryos were fixed and stained as described above. Whole-mount sea urchin embryos were observed with an inverted confocal laser scanning microscope (CLSM) Zeiss-510 equipped with a $25 \times$ water immersion objective. Each image was acquired with an Argon $488 \mathrm{~nm}$ wavelength $(\lambda)$ laser to detect TUNEL fluorescence (green).

\subsection{Cell Culture and Cell Viability Assay}

The human myelomonocytic cell line U937 was cultured in Roswell Park Medium Institute (RPMI) medium supplemented with $10 \%$, fetal bovine serum and $1 \%$ penicillin/streptomycin at $37{ }^{\circ} \mathrm{C}$ in a humidified atmosphere containing 5\% CO2. Cell viability assay was performed using neutral red viability test as described in [24]. RPMI medium, L-glutamine $200 \mathrm{mM}$, penicillin $5000 \mathrm{IU} / \mathrm{mL} /$ streptomycin $5000 \mu \mathrm{g} / \mathrm{mL}$ and PBS (phosphate buffer saline) tablets were purchased from Life Technologies (Monza, Italy); fetal bovine serum from Cambrex (Milano, Italy). Neutral red solution $(0.33 \% \mathrm{v} / \mathrm{v})$, trypan blue solution $(0.4 \% \mathrm{v} / \mathrm{v})$, propidium iodide were from Sigma-Aldrich (Milano, Italy).

\subsection{Annexin V Assay}

Phosphatidylserine (PS) exposure was measured using the binding of fluorescein-isothiocyanate-labeled (FITC) Annexin-V to PS, as indicated in the manufacturer's protocol (Enzo Life Sciences; Vinci, Florence, Italy). Briefly, cells $\left(2 \times 10^{6}\right.$ per $\left.\mathrm{mL}\right)$ were incubated in the presence of the tested compounds for the indicated times. Cells were collected and centrifuged at $400 \times g$ for 5 min, washed in PBS and suspended in binding buffer (10 mM HEPES, pH 7.4; $140 \mathrm{mM} \mathrm{NaCl} ; 2.5 \mathrm{mM} \mathrm{CaCl}_{2}$ ). Annexin V FITC $(2 \mu \mathrm{L})$ and propidium iodide $(25 \mu \mathrm{g} / \mathrm{mL})$ were added for $10 \mathrm{~min}$ in the dark, at room temperature and analyzed with flow cytometer (FACS-Calibur; Becton Dickinson, Mountain View, CA, USA) equipped with argon laser $(488 \mathrm{~nm})$ and 530 and $585 \mathrm{~nm}$ filters for FITC and phycoerythrin, respectively. Low fluorescence debris and necrotic cells, permeable to propidium iodide, were gated out before analysis. Data were analyzed using CellQuest software (Becton Dickinson, Milano, Italy).

\subsection{Caspase Assay}

To determine caspase- 3 enzymatic activity, $2 \times 10^{6}$ cells were incubated in the presence of the tested compounds for 6 or $24 \mathrm{~h}$. Cells were collected and centrifuged at $400 \times g$ for 5 min, washed twice in PBS and suspended in lysis buffer (10 mM HEPES, pH 7.4; $2 \mathrm{mM}$ ethylenediaminetetracetic acid; 0.1\% [3-(3-cholamidopropyl) dimethylammonio]-1-propanesulfonate; $5 \mathrm{mM}$ dithiothreitol; $1 \mathrm{mM}$ phenylmethylsulfonyl fluoride; $10 \mu \mathrm{g} / \mathrm{mL}$ pepstatin-A; $10 \mu \mathrm{g} / \mathrm{mL}$ apronitin; $20 \mu \mathrm{g} / \mathrm{mL}$ leupeptin). Cell 
extracts $(10 \mu \mathrm{g})$ were added to reaction buffer containing the conjugated amino-4-trifluoromethyl coumarin (AFC) substrates: benzyloxycarbonyl-Asp(OMe)-Glu(OMe)-Val-Asp(OMe)-AFC (ZDEVD-AFC). Samples were incubated at $37{ }^{\circ} \mathrm{C}$ for $30 \mathrm{~min}$. Upon proteolytic cleavage of the caspase- 3 substrate, the free fluorochrome AFC was detected by a spectrofluorometer multiplate reader (FL-500; Bio-Tek Instruments, Milano, Italy) with excitation $395 \pm 20 \mathrm{~nm}$ and emission at $530 \pm 20 \mathrm{~nm}$. To quantify enzymatic activity, we calculated an AFC standard curve. Caspase-3 specific activity was determined as nmol of AFC produced per min per $\mu \mathrm{g}$ proteins at $37^{\circ} \mathrm{C}$ using saturating substrate concentrations $(50 \mu \mathrm{M})$ [24]. Fold increase in caspase-3 was determined by direct comparison with the level of $0.1 \%$ DMSO-treated cells.

\section{Conclusions}

Biological organisms benefit from the ability to develop and use chemicals to communicate with each other, to defend themselves from predators and pathogens, to prey and to mate. Apart from their ecological and physiological role, these products have a promising potential as evolutionary preselected lead structures for biotechnological applications. It is therefore not surprising that in this work eco-physiological considerations on diatom oxylipins are demonstrated to be predictive for the synthesis of a novel compound with apoptotic activity against tumor cell lines. Although compound 22, as it is, is not sufficiently potent to suggest further evaluation for antitumor activity, its chemical structure is easy to modify in order to improve pharmacological and biological activity. In this sense, the present study supports the possibility of replacing expensive high-throughput screening platforms for drug discovery using chemical synthesis inspired by bioactive secondary metabolites.

\section{Acknowledgments}

We thank Davide Caramiello from the Aquaculture of Marine Organisms Facility at the Stazione Zoologica Anton Dohrn, for his technical support in sea urchin maintenance and gamete collection. $\mathrm{AF}$ is grateful to Regione Campania for the financial support through the FAS-APQ projects-Action RT02.

\section{Conflicts of Interest}

The authors declare no conflict of interest.

\section{References}

1. D’Ippolito, G.; Cutignano, A.; Briante, R.; Febbraio, F.; Cimino, G.; Fontana, A. New C $_{16}$ Fatty Acid-Based Oxylipin Pathway in the Marine Diatom Thalassiosira rotula. Org. Biomol. Chem. 2005, 3, 4065-4070.

2. Fontana, A.; d'Ippolito, G.; Cutignano, A.; Romano, G.; Lamari, N.; Gallucci, A.M.; Cimino, G.; Miralto, A.; Ianora, A. LOX-induced peroxidation mechanism responsible for the detrimental effect of marine diatoms on zooplankton grazers. ChemBioChem 2007, 8, 1810-1818.

3. Funk, C.D. Prostaglandins and leukotrienes: Advances in eicosanoid biology. Science 2001, 294, 1871-1875. 
4. Kuhn, H.; Walther, M.; Kuban, R.J. Mammalian arachidonate 15-LOXs. Structure, function, and biological implications. Prostaglandins Other Lipid Mediat. 2002, 68-69, 263-290.

5. Feussner, I.; Wasternack, C. The lipoxygenase pathway. Annu. Rev. Plant Biol. 2002, 53, 275-297.

6. Wasternack, C. Jasmonates: An update on biosynthesis, signal transduction and action in plant stress response, growth and development. Ann. Bot. 2007, 100, 681-697.

7. Matsui, K. Green leaf volatiles: Hydroperoxide lyase pathway of oxylipin metabolism. Curr. Opin. Plant Biol. 2006, 9, 274-280.

8. Miralto, A.; Barone, G.; Romano, G.; Poulet, S.A.; Ianora, A.; Russo, G.L.; Buttino, I.; Mazzarella, G.; Laabir, M.; Cabrini, M.; et al. The insidious effect of diatoms on copepod reproduction. Nature 1999, 402, 173-176.

9. Ianora, A.; Miralto, A. Toxigenic effects of diatoms on grazers, phytoplankton and other microbes: A review. Ecotoxicology 2010, 19, 493-511.

10. d'Ippolito, G.; Lamari, N.; Montresor, M.; Romano, G.; Cutignano, A.; Gerecht, A.; Cimino, G.; Fontana, A. 15S-Lipoxygenase metabolism in the marine diatom Pseudo-nitzschia delicatissima. New Phytol. 2009, 183, 1064-1071.

11. Caldwell, G.S. The influence of bioactive oxylipins from marine diatoms on invertebrate reproduction and development. Mar. Drugs 2009, 7, 367-400.

12. Ianora, A.; Romano, G.; Carotenuto, Y.; Esposito, F.; Roncalli, V.; Buttino, I.; Miralto, A. Impact of the diatom oxylipin 15(S)-HEPE on the reproductive success of the copepod Temora stylifera. Hydrobiologia 2011, 666, 265-275.

13. Cutignano, A.; Lamari, N.; d'Ippolito, G.; Manzo, E.; Cimino, G.; Fontana, A. Lipoxygenase products in marine diatoms: A concise analytical method to explore the functional potential of oxylipins. J. Phycol. 2011, 47, 233-243.

14. Romano, G.; Russo, G.L.; Buttino, I.; Ianora, A.; Miralto, A. A marine diatom-derived aldehyde induces apoptosis in copepod and sea urchin embryos. J. Exp. Biol. 2003, 206, 3487-3494.

15. Romano, G.; Miralto, A.; Ianora, A. Teratogenic effects of diatom metabolites on sea urchin Paracentrotus lividus embryos. Mar. Drugs 2010, 8, 950-967.

16. Adolph, S.; Bach, S.; Blondel, M.; Cueff, A.; Moreau, M.; Pohnert, G.; Poulet, S.A.; Wichard, T.; Zuccaro, A. Cytotoxicity of diatom-derived oxylipins in organisms belonging to different phyla. J. Exp. Biol. 2004, 207, 2935-2946.

17. Salvador, J.A.R.; Sae Melo, M.L.; Campos Neves, A.S. Copper-catalysed allylic oxidation of $\Delta 5$-steroids by t-butyl hydroperoxide. Tetrahedron Lett. 1997, 38, 119-122.

18. Suryawanshi, S.N.; Fuchs, P.L. Synthesis of gamma-hydroxy enones via persulfate oxidation of dienyl ethers. Tetrahedron Lett. 1981, 22, 4201-4204.

19. Russo, M.; Nigro, P.; Rosiello, R.; D’Arienzo, R.; Russo, G.L. Quercetin enhances CD95- and TRAIL-induced apoptosis in leukemia cell lines. Leukemia 2007, 21, 1130-1133.

20. Caldwell, G.S.; Olive, P.J.W.; Bentley, M.G. Inhibition of embryonic development and fertilization in broadcast spawning marine invertebrates by water soluble diatom extracts and the diatom toxin 2-trans,4-trans decadienal. Aquat. Toxicol. 2002, 60, 123-137. 
21. Poulet, S.A.; Richer de Forge, M.; Cueff, A.; Lennon, J.F. Double labelling methods used to diagnose apoptotic and necrotic cell degradations in copepod nauplii. Mar. Biol. 2003, 143, 889-895.

22. Ianora, A.; Miralto, A.; Poulet, S.A.; Carotenuto, Y.; Buttino, I.; Romano, G.; Casotti, R.; Pohnert, G.; Wichard, T.; Colucci-D'Amato, L.; et al. Aldehyde suppression of copepod recruitment in blooms of a ubiquitous planktonic diatom. Nature 2004, 429, 403-407.

23. Blanchette, M.A.; Choy, W.; Davis, J.T.; Essenfeld, A.P.; Masamune, S.; Roush, W.R.; Sakai, T. Horner-wadsworth-emmons reaction: Use of lithium chloride and an amine for base-sensitive compounds. Tetrahedron Lett. 1984, 25, 2183-2186.

24. Russo, M.; Palumbo, R.; Mupo, A.; Tosto, M.; Iacomino, G.; Scognamiglio, A.; Tedesco, I.; Galano, G.; Russo, G.L. Flavonoid quercetin sensitizes a CD95-resistant cell line to apoptosis by activating protein kinase $\mathrm{C}_{\alpha}$. Oncogene 2003, 22, 3330-3342.

(C) 2013 by the authors; licensee MDPI, Basel, Switzerland. This article is an open access article distributed under the terms and conditions of the Creative Commons Attribution license (http://creativecommons.org/licenses/by/3.0/). 